\title{
Molecular characterization of genes responsible for biofilm formation in Staphylococcus aureus isolated from mastitic cows
}

\author{
Eman Shafeek Ibrahim¹(i), Amany Ahmed Arafa ${ }^{1}$ (i), Sohad Mohamed Dorgam¹(i), Rasha Hamdy Eid² (iD, \\ Nagwa Sayed Atta1 (iD, Wahid Hussein El-Dabae ${ }^{1}$ (iD) and Eslam Gaber Sadek ${ }^{1}$ (D)
}

1. Department of Microbiology and Immunology, National Research Centre, Dokki, Giza, Egypt; 2. Udder Health and Neonatal Disease, Animal Reproduction Research Institute, Giza, Egypt.

Corresponding author: Wahid Hussein El-Dabae, e-mail: dr_wahidhussein@yahoo.com

Co-authors: ESI: dr.eman911@yahoo.com, AAA: dr.amanyahmed@yahoo.com, SMD, sohad_dorgham@yahoo.com, RHE: rashahamdy815@yahoo.com, NSA: nagwaata@yahoo.com, EGS: tayemeslam2014@gmail.com

Received: 06-09-2021, Accepted: 31-12-2021, Published online: 30-01-2022

doi: www.doi.org/10.14202/vetworld.2022.205-212 How to cite this article: Ibrahim ES, Arafa AA, Dorgam SM, Eid RH, Atta NS, El-Dabae WH, Gaber ES (2022) Molecular characterization of genes responsible for biofilm formation in Staphylococcus aureus isolated from mastitic cows, Veterinary World, 15(1): 205-212.

\begin{abstract}
Background and Aim: Mastitis is considered a significant disease of lactating animals. There are new attitudes for recognizing genes responsible for causing this disease to overcome and change the manipulation of this problem. This study aimed to isolate and identify Staphylococcus aureus strains from mastitic bovine animals and detect some specific biofilm-forming genes (icaA, icaD, and biofilm-associated protein [bap] genes $c l f A$, fnbA, agrI, agrII, agrIII, agrIV, and cna).

Materials and Methods: A total of 121 mastitic milk samples were analyzed using biochemical tests (catalase test, oxidativefermentative test, and coagulase test) and Gram stain. Multiplex polymerase chain reaction was applied to characterize biofilm genes (icaA, icaD, bap, clfA, and fnbA) in addition to (agrI, agrII, agrIII, agrIV, and cna).

Results: Among the 121 milk samples, 35 staphylococci isolates were derived with an incidence of 28.92\% (35/121); among them, 19 are coagulase positive. Ninety percent of the isolates had ica genes (icaA and icaD) while bap gene was not recognized in any isolate. In addition, the incidence of $f n b A$, can, and $c l f A$ was $89.5 \%$ each. The prevalence of agr specific groups (agrI, agrII, agrIII, and agrIV) was $78.9 \%, 52.6 \%, 10.5 \%$, and $15.8 \%$, respectively.
\end{abstract}

Conclusion: This study concluded that $S$. aureus has variant mechanisms of pathogenicity to form biofilm devoid of carrying a specific gene.

Keywords: biofilm genes, mastitis, molecular identification, Staphylococcus aureus.

\section{Introduction}

Mastitis in bovine is the most widespread disease among dairy cattle. Consequently, it influences its production due to a combination of different factors such as host, climate, and infectious agents and reduces the quantity and quality of produced milk [1]. The primary cause of bovine mastitis is Staphylococcus aureus, responsible for a dramatic decrease in both quality and quantity of milk production, resulting in significant economic consequences in the dairy farms [2].

$S$. aureus strains have immense pathogenicity (e.g., encoding virulence factor genes and antibiotic resistance) and several ways to infect humans, such as through foodstuffs, skin infection during the milking process, and direct contact with contaminated fomites. Subsequently, animals producing food, especially cows, are a major route for $S$. aureus to enter the food

Copyright: Ibrahim, et al. Open Access. This article is distributed under the terms of the Creative Commons Attribution 4.0 International License (http://creativecommons.org/licenses/ by/4.0/), which permits unrestricted use, distribution, and reproduction in any medium, provided you give appropriate credit to the original author(s) and the source, provide a link to the Creative Commons license, and indicate if changes were made. The Creative Commons Public Domain Dedication waiver (http:// creativecommons.org/publicdomain/zero/1.0/) applies to the data made available in this article, unless otherwise stated. chain [3]. Thus, identifying the virulence factors and mechanisms of this pathogen involved in such criteria is important. Furthermore, how they assist in adhering and colonizing the mammary glands' epithelium cells, leading to persistence, successful foundation, and continuance in the host tissue. The most common virulence factors that aid staphylococci in adhering and colonizing the epithelium of the mammary gland are related to their capacity to form biofilms, resulting in loss of immunological defenses and frequent infections. Furthermore, staphylococcal adhesions have been shown to be necessary for binding host cells [4]. Biofilm formation may lead to continual contamination or infection because biofilm cells are highly resistant to hygiene measures, the effect of antimicrobial agents, and host immunity [5]. The process of biofilm formation by Staphylococcus spp. requires the contribution of different genes and proteins [6]. First, adherence of bacterial cells to a surface is initiated by a capsular antigen polysaccharide/adhesin (PS/A). Following that, growth occurs to create a multi-layered biofilm that induces polysaccharide intercellular adhesin (PIA) production. The intercellular adhesion operon is responsible for PIA and PS/A synthesis in staphylococcal species (ica), formed by the icaA, icaB, icaC, and icaD encoding genes as well 
as regulatory gene, icaR, carrying icaA, icaB, icaC, and icaD proteins [7].

Furthermore, $S$. aureus has many adhesins that play an important role in the onset of pathogenicity through the binding of host tissues that are considered essential factors of virulence. These adhesins include fibronectin-binding proteins ( $f n b A$ and $f n b B)$, clumping factors ( $c l f A$ and $c l f B$ ), collagen-binding protein (cna), biofilm-associated protein (bap) [8], and collagen-binding protein (cna) [9], which are considered essential virulence factors in binding host cells, colonization, and invasion [10]. The accessory gene regulatory ( $a g r)$ system is fundamental in $S$. aureus virulence gene expression. The $a g r$ operon, which includes the genes $\operatorname{agr} A, \operatorname{agr} B, \operatorname{agr} C$, and $\operatorname{agr} D$, controls more than 70 genes in $S$. aureus, 23 of which regulate infectivity [11]. Furthermore, $S$. aureus genes could be divided into four groups of (agr I, agr II, agr III, and $a g r I V$ ) genes. They are different in their characteristics and occurrence in various geographical areas. Thus, it is necessary to determine the main types in each region [12].

This study aimed to isolate and identify $S$. aureus strains obtained from mastitic bovine animals and specify the involved genes in biofilm formation (icaA, icaD, bap, clfA, fnbA, AgrI, AgrII, AgrIII, AgrIV, and cna).

\section{Materials and Methods}

\section{Ethical approval}

This study was approved (no. 12020232/2019)

by Ethical Committee for Medical Research at the National Research Centre, Egypt.

\section{Study period and location}

The study was conducted from January to March 2020. The study was conducted at National Research Center, Dokki, Egypt. The samples were processed at the National Research center, Veterinary Research Division, Microbiology and Immunology Department Laboratory.

\section{Collection of samples}

One hundred and twenty one affected quarter milk samples (quarter selected based on physical examination; appearance of inflammation as redness and swelling) were obtained from 40 cows suffered from mastitis and did not receive any medical treatment for 7-10 days in private farms in Giza Governorate, Egypt. Those farms did not implement the required hygienic measures to control mastitis and other infectious diseases. The milking process was performed using a traditional method.

Before the milk collection, the animals did not receive antibiotic treatment for at least 1 month. The collection of milk samples was conducted under complete aseptic conditions according to Oliver et al. [13].

\section{Isolation and identification of $\boldsymbol{S}$. aureus}

Every milk sample was cultured on two plates: Columbia Agar base with 5\% defibrinated sheep blood
(Oxoid, UK) and mannitol salt agar (Oxoid). The tested plates were incubated at $37 \pm 1^{\circ} \mathrm{C}$ for $24-48 \mathrm{~h}$. According to colony morphology, Gram staining, in addition to catalase reaction, and oxidative-fermentative test, all isolates were identified as staphylococci. Coagulase test was used to characterize all $S$. aureus strains [14].

\section{DNA extraction}

DNA milk samples were extracted using the QIAamp DNA Mini kit (Qiagen, Germany, GmbH) with some modifications (temperature adjustment at $25^{\circ} \mathrm{C}$ and $\mathrm{pH}$ set at 4.0 ) to the manufacturer's instructions.

\section{Oligonucleotide primers}

The utilized primers of polymerase chain reaction (PCR) from Metabion (Germany) are listed in Table-1 [8,15-19]. PCR was conducted in an Applied Biosystems 2720 thermal cycler (Applied Biosystems, USA).

\section{PCR products}

PCR products were separated by electrophoresis at room temperature $\left(25^{\circ} \mathrm{C}\right)$ on $1.5 \%$ agarose gel (AppliChem, Germany, GmbH) in $1 \times$ Tris-borateEDTA buffer with gradients of $5 \mathrm{~V} / \mathrm{cm}$. A gel documentation system (Alpha Innotech, Biometra, Germany) was used to photograph the gel (Gel documentation system; Biometra, Germany) and the data were evaluated using a computer software (Genesys image capture, Biometra, Germany).

\section{Results and Discussion}

Bovine mastitis is a significant disease in lactating herds worldwide [20]. S. aureus is considered the most common causative agent, leading to more virulent mastitis in cows. It possesses the greatest risk in dairy production in many countries [21].

In the current study, a total of 35 staphylococci isolates have been isolated with a prevalence of $28.92 \%$ (35/121). The identified prevalence of $S$. aureus and Coag-ve staphylococci other than $S$. aureus was $57.14 \%(20 / 35)$ and and $42.85 \%$ (15/35). All staphylococci isolates were confirmed using $16 \mathrm{~S} r R N A$ gene, as shown in Figure-1.

$S$. aureus isolated from subclinical mastitis cow was $36 \%$ [22] and less than the prevalence (6.5\%) detected by Haltia et al. [23]. According to this study, the high prevalence of $S$. aureus may result from contaminated milk utensils and Milker's hands.

The possibility of $S$. aureus infection occurring is related to its capacity to release different factors of virulence that contribute to the invasion of the bacteria [24]. The formation of biofilm increased the virulence of $S$. aureus. In addition, strains can create biofilms that possess higher antibiotic tolerance, antiseptics, and poor environmental conditions [25]. The genes of ica are responsible for slime formation in $S$. aureus by controlling PIA production. It can also determine the ability of $S$. aureus strains to generate biofilm. 


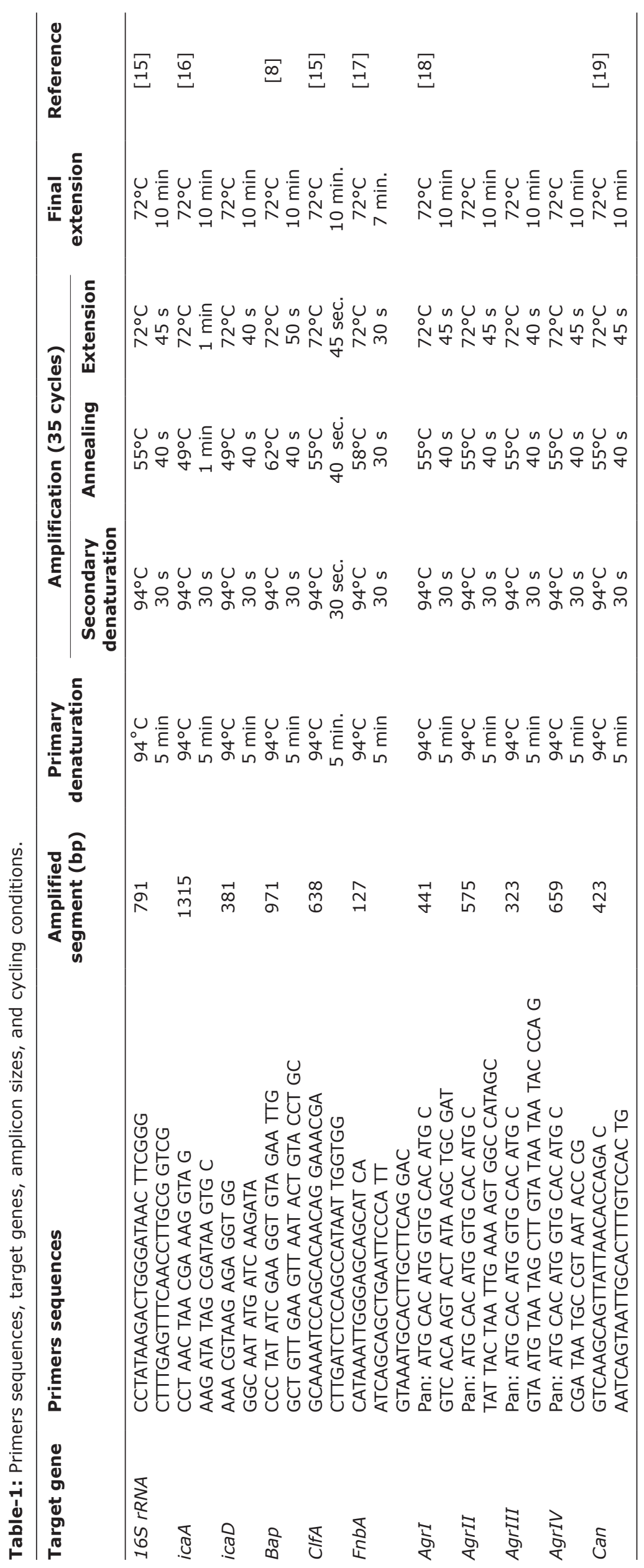


Namvar et al. [26] found that $S$. aureus could not generate biofilm unless strains were positive for the ica $D$ gene. Strains posing the ica ADBC group were likely to generate biofilm [27]. Among 90\% of S.aureus isolates (Table-2), ica genes (ica A and ica $D$ ) were detected (Figures-2 and 3).

These results almost agree with other findings as ica genes were identified in all isolates [3]. While
Gowrishankar et al. [28] detected those isolates of $S$. aureus in India carry ica genes in a percentage of 84.13\%. In Mexico, Avila-Novoa et al. [29] identified the genes in $52.3 \%$ of isolates.

The bap gene implicates biofilm formation by promoting primary attachment and adhesion to inert and live surfaces [30]. This study showed that all the tested strains $(100 \%)$ were negative for the bap gene (Figure-4).

Table-2: Polymerase chain reaction results for biofilm genes.

\begin{tabular}{|c|c|c|c|c|c|c|c|c|c|c|c|}
\hline $\begin{array}{l}\text { Coagulase positive } \\
\text { staphylococcus sample }\end{array}$ & $16 S$ rRNA & icaA & icaD & $f n b A$ & can & bap & $c / f A$ & agrI & agrII & agrIII & agrIV \\
\hline 1 & + & + & + & + & + & - & + & - & + & - & + \\
\hline 2 & + & + & + & + & + & - & + & + & - & - & - \\
\hline 3 & + & + & + & + & + & - & + & + & - & - & + \\
\hline 4 & + & + & + & - & - & - & - & - & - & - & - \\
\hline 5 & + & + & + & + & + & - & + & + & - & + & - \\
\hline 6 & + & - & - & - & - & - & - & - & - & - & - \\
\hline 7 & + & + & + & + & + & - & + & - & + & - & + \\
\hline 8 & + & + & + & + & + & - & + & + & + & - & - \\
\hline 9 & + & + & + & + & + & - & + & + & + & - & - \\
\hline 10 & + & + & + & + & + & - & + & + & - & - & - \\
\hline 11 & + & + & + & + & + & - & + & + & + & - & - \\
\hline 12 & + & + & + & + & + & - & + & + & - & - & - \\
\hline 13 & + & + & + & + & + & - & + & + & + & - & - \\
\hline 14 & + & + & + & + & + & - & + & + & + & - & - \\
\hline 15 & + & + & + & + & + & - & + & + & - & + & - \\
\hline 16 & + & + & + & + & + & - & + & + & + & - & - \\
\hline 17 & + & + & + & + & + & - & + & + & - & - & - \\
\hline 18 & + & + & + & + & + & - & + & + & + & - & - \\
\hline 19 & + & + & + & + & + & - & + & + & + & - & - \\
\hline
\end{tabular}

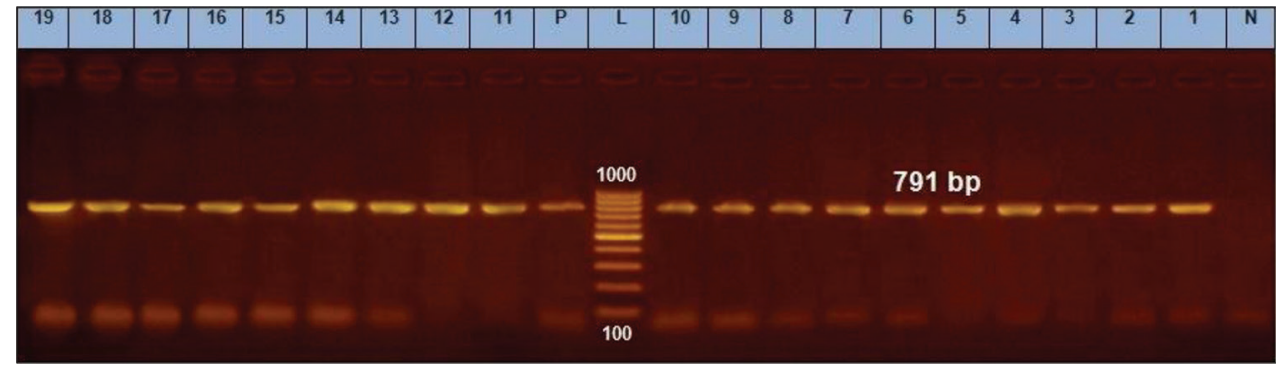

Figure-1: $16 \mathrm{~S}$ rRNA gene at 791bp; Lanes (1-11) are positive, Lane L: 1000 bp ladder, N: (negative control) and $\mathrm{P}$ : (positive control).

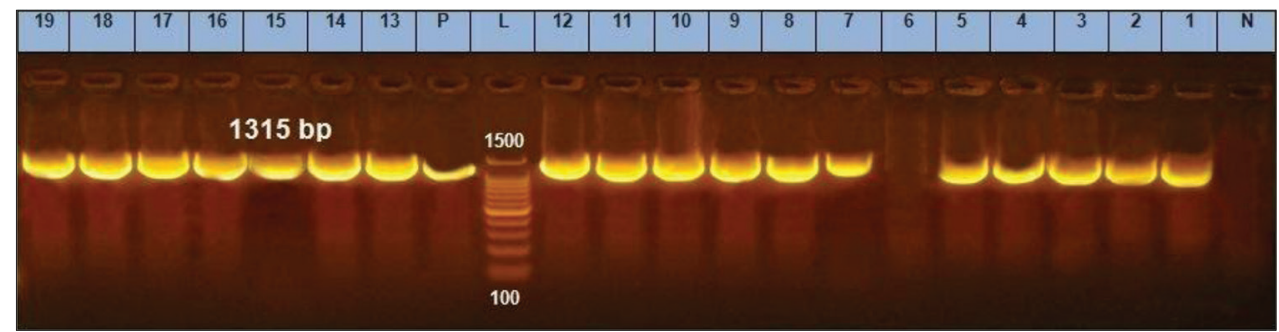

Figure-2: icaA gene at 1315bp; Lanes 6 is negative, Lane L: 1000 bp ladder, N: (Negative control) and P: (Positive control).

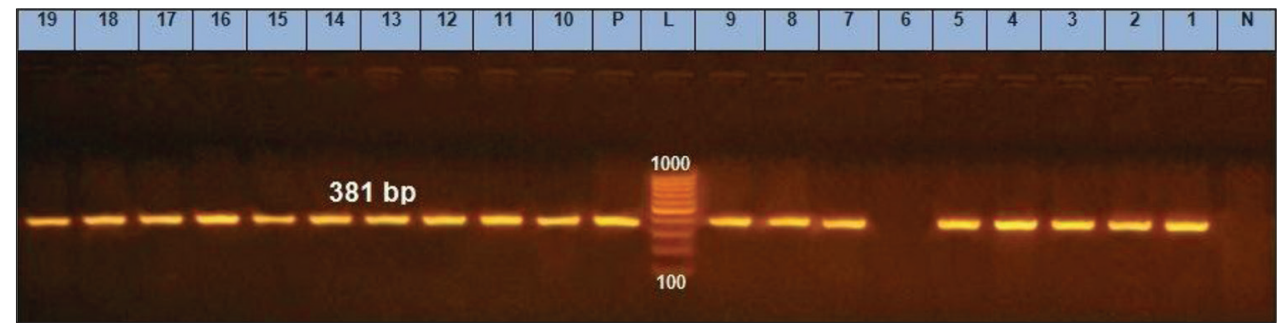

Figure-3: icaD gene at 381 bp; Lanes 6 is negative, Lane L: 1000 bp ladder, N: (Negative control) and P: (Positive control). 
According to Vautor et al. [31], the absence of bap indicates that the ica-dependent pathway is predominantly responsible for adhesion and biofilm development in strains. Bissong et al. [32] found that the occurrence of the bap gene was limited (12, 15.6\%). Li et al. [33] identified bap gene in $43.9 \%$ of $S$. aureus strains biofilm producers, proving the significance of bap gene in biofilm production. Our results are in agreement with Xu et al. [34], who were unable to detect bap gene in $S$. aureus recovered from subclinical mastitic cow. Khoramrooz et al. [35] and Darwish and Asfour [36] detected expression of bap gene in 5\% and $2.5 \%$ among obtained isolates, respectively. Our results showed that the $i c a$-gene process could sometimes be essential for attachment and formation of biofilm among isolated strains; this can be a possible explanation for our finding.

The $f n b A$ genes appear to be necessary for bacterial invasion and adhesion, and they may be associated with their ability to form biofilms. The incidence of expression of the surface protein genes for S. aureus (fnbA, can, and clfA) was $89.5 \%$ for each gene as reported in Table-2; these results demonstrated resemblance and minor variations to earlier studies; Peerayeh et al. [37] revealed that clfA and fnbA (Figures-5 and 6) encoding genes had been found in each of the tested isolates (20 strains), with can gene are being found in $20 \%$ of identified

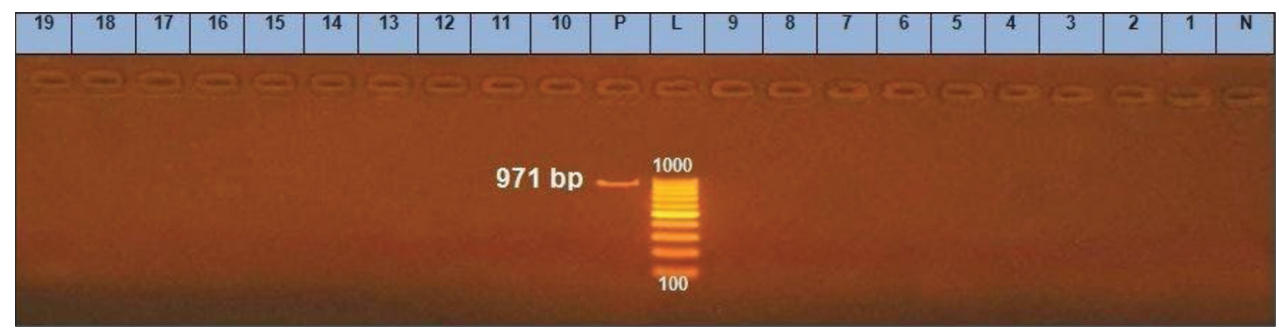

Figure-4: bap gene at 971bp; Lane (1-19) are negative, Lane L: 1000 bp ladder, N: (Negative control) and P: (Positive control).

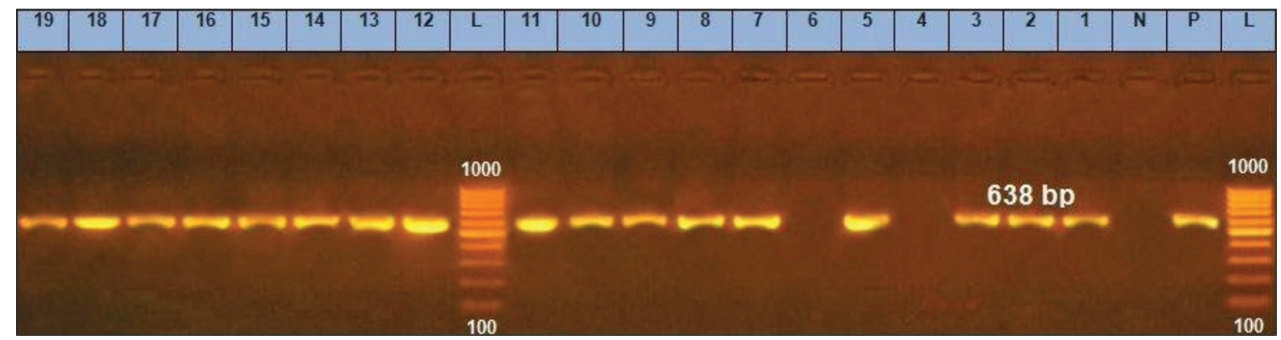

Figure-5: clfA gene at 638bp; Lanes (4 and 6) are negative, Lane L: 1000 bp ladder, N: (Negative control) and P: (Positive control).

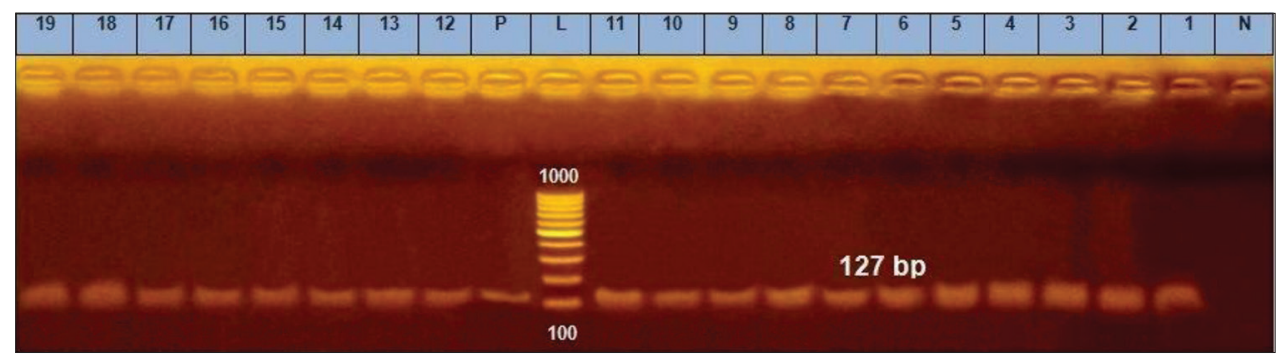

Figure-6: fnbA gene at 127bp; Lane L: 1000 bp ladder, N: (Negative control) and P: (Positive control).

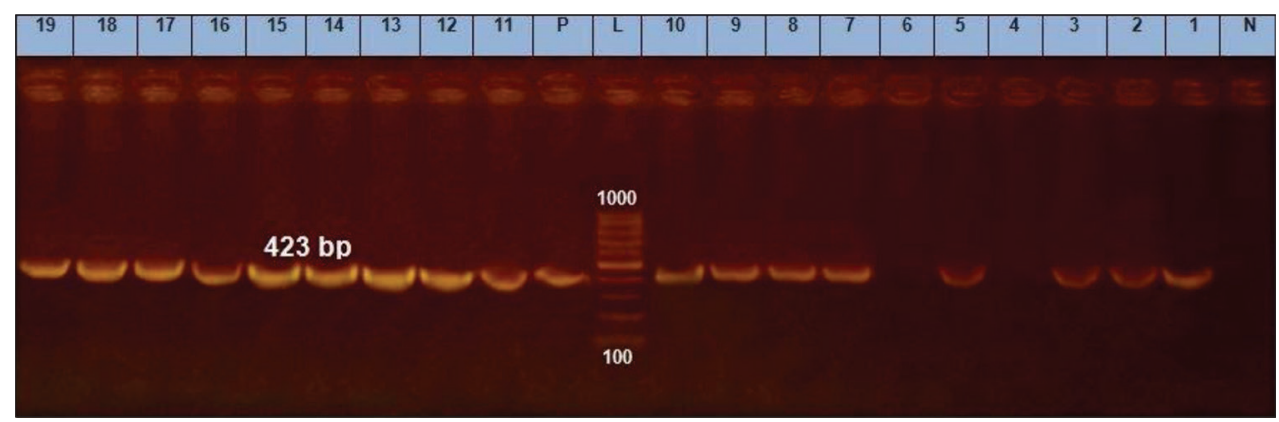

Figure-7: cna gene at 423 bp; Lanes (4 and 6) are negative, Lane L: 1000 bp ladder, N: (Negative control) and P: (Positive control). 
isolates(Figure-7). In contrast, Ote et al. [38], and Ikawaty et al. [39] observed a higher prevalence of can gene (31.9\% and $49 \%$, respectively).

$S$. aureus strains have been divided into four categories, agrI to agrIV, [18] based on differences in their $a g r$ genes. The $a g r$-encoded quorum-sensing system's important function in virulence regulation makes it an appropriate target for antimicrobial drug development. According to
Table-2, the prevalence of $a g r$ specificity groups (agrI, agrII, agrIII, and agrIV) were $78.9 \%, 52.6$, $10.5 \%$, and $15.8 \%$, respectively. According to Figures- 8 to 11 , our results showed that $a g r \mathrm{I}$ was the most common type found in isolated $S$. aureus. Javdan et al. [40], and Cheraghi et al. [41], stated that the most dominant type was agr Type I. It is said that definite groups of $a g r$ in $S$. aureus are implicated in certain diseases, such as isolates that possess agrI

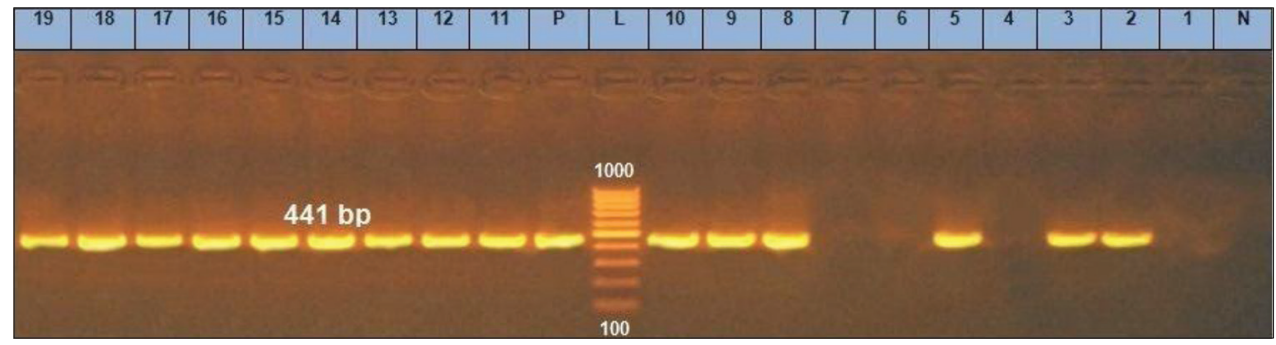

Figure-8: agrI gene at 441bp; Lanes $(1,4,6,7)$ are negative, Lane L: 1000 bp ladder, N: (Negative control) and P: (Positive control).

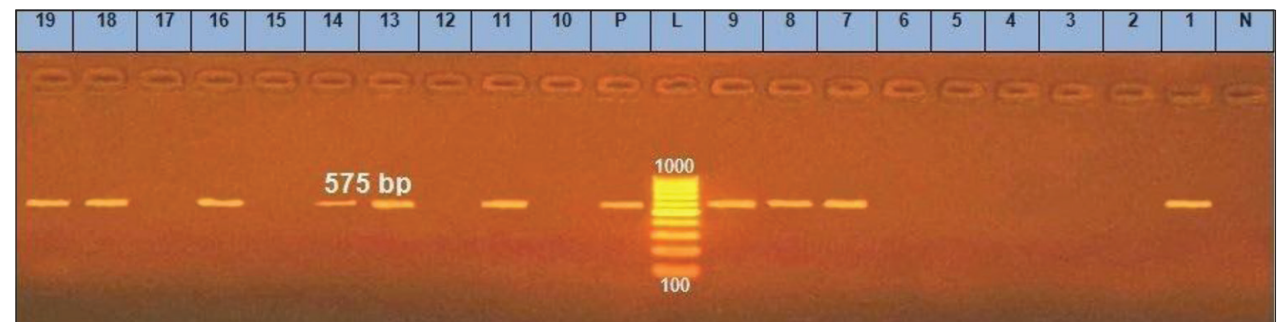

Figure-9: agrII gene at 575bp; Lanes $(2,3,4,5,6,10,12,15,17)$ are negative, Lane L: 1000 bp ladder, N: (Negative control) and P: (Positive control).

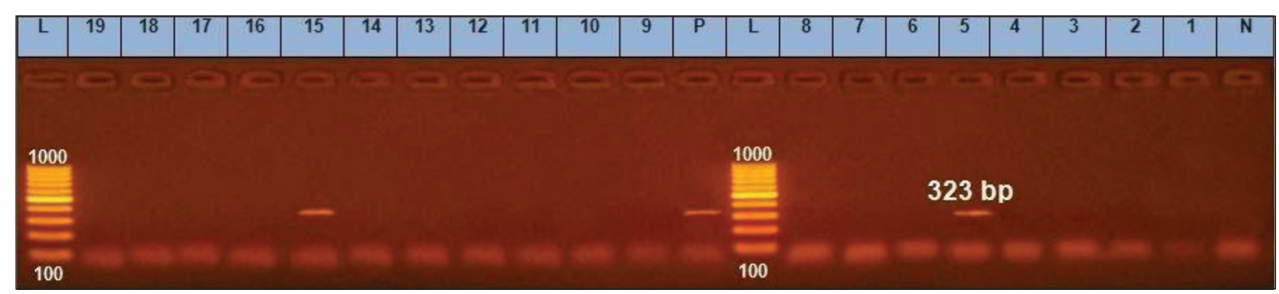

Figure-10: agrIII gene at 323bp; Lanes (5 and 15) are positive, Lane L: 1000 bp ladder, N: (Negative control) and P: (Positive control).

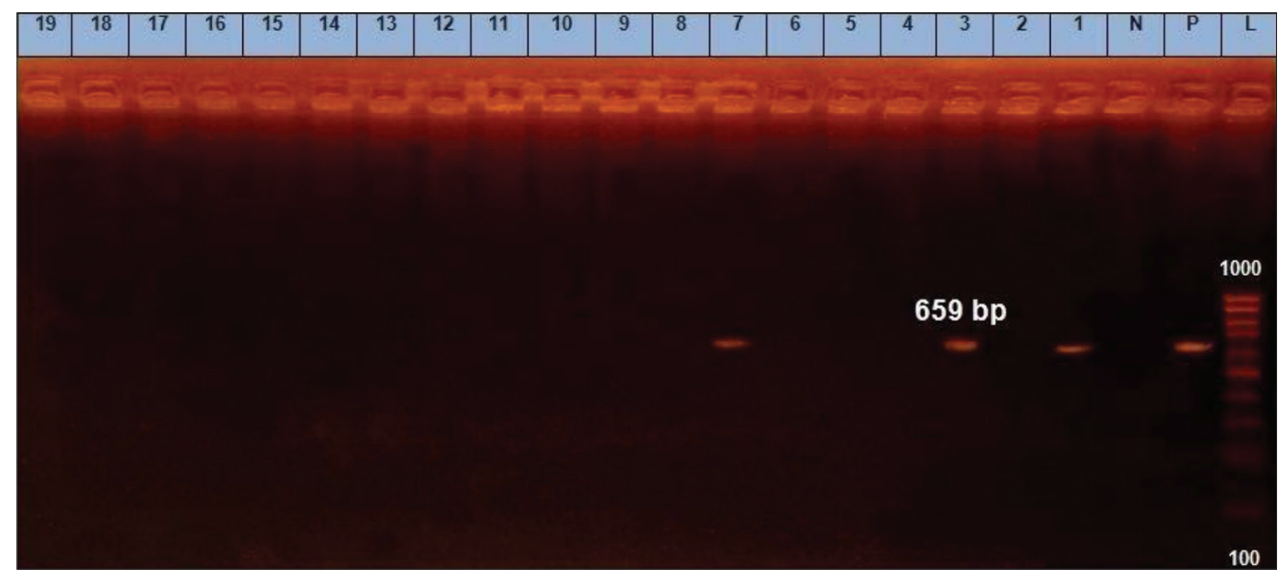

Figure-11: agrIV gene at 659bp; Lanes $(1,3,7)$ are positive, Lane L: 1000 bp ladder, N: (Negative control) and P: (Positive control). 
are related to bacteremia and persistent diseases [42]. The development of biofilm is a complex process involving numerous factors such as poor hygienic measures and poor management of milking practices.

\section{Conclusion}

It can be concluded that the variant mechanisms of pathogenicity induced by $S$. aureus to form biofilm without needing a specific gene. It is necessary to identify the presence of genes related to biofilm production as formation of biofilm results in attachment to glandular udder tissue and biomaterials, thus increasing the virulence of bacteria. Besides, the biofilm's existence increases the bacterial resistance to antibiotics, consequently complicating its treatment. This study presents preliminary results for additional in-depth prospect studies. Finally, good hygienic measures and habits, in addition to good management of milking practices, can reduce the incidence of $S$. aureus mastitis.

\section{Authors' Contributions}

RHE and EGS: Collected the samples, applied the practical work including isolation of $S$. aureus and identification of obtained isolates. ESI, WHE and AAA: Planned the work, applied the practical work including isolation of $S$. aureus and identification of obtained isolates, PCR and revised the manuscript. SMD: Carried out PCR and drafted the manuscript. NSA: Revised the manuscript. All authors read and approved the final manuscript.

\section{Acknowledgments}

The authors would like to express their appreciation to all staff members of the Microbiology and Immunology Department for their support during the study. The study was funded by National Research Centre, Egypt (Internal project No. 12020232).

\section{Competing Interests} interests.

The authors declare that they have no competing

\section{Publisher's Note}

Veterinary World remains neutral with regard to jurisdictional claims in published institutional affiliation.

\section{References}

1. Hogeveen, H. and Van Der Voort, M. (2017). Assessing the economic impact of an endemic disease: The case of mastitis. Rev. Sci. Tech., 36(1): 217-226.

2. Merz, A., Stephan, R. and Johler, S. (2016) Staphylococcus aureus isolates from goat and sheep milk seem to be closely related and differ from isolates detected from bovine milk. Front. Microbiol., 7: 319.

3. Wang, W., Li, X., Jiang, T., Peng, Z., Xu, J., Yi, L., Li, F., Fanning, S. and Baloch, Z. (2018) Prevalence and characterization of Staphylococcus aureus cultured from raw milk taken from dairy cows with mastitis in Beijing, China. Front. Microbiol., 9: 11-23.
4. Ren, Q., Liao, G., Wu, Z., Lv, J. and Chen, W. (2020) Prevalence and characterization of Staphylococcus aureus isolates from subclinical bovine mastitis in Southern Xinjiang, China. J. Dairy Sci., 103(4): 3368-3380.

5. Song, M., Li, Q., Zhang, Y., Song, J., Shi, X. and Shi, C. (2016) Biofilm formation and antibiotic resistance pattern of dominant Staphylococcus aureus clonal lineages in China. J. Food Saf., 37(2): 12304.

6. Heilmann, C. (2011) Adhesion mechanisms of staphylococci. In: Heilmann, C., editor. Bacterial Adhesion. Springer, New York. p105-123.

7. Gad, G.F.M., El-Feky, M.A., El-Rehewy, M.S., Hassan, M.A., Abbolella, H. and Abd El-Baky, R.M. (2009) Detection of icaA, icaD genes and biofilm production by Staphylococcus aureus and Staphylococcus epidermidis isolated from urinary tract catheterized patients. J. Infect. Dev. Ctries. 3(5): 342-351.

8. Cucarella, C., Solano, C., Valle, J., Amorena, B., Lasa, I. and Penadés, J.R. (2001) Bap, a Staphylococcus aureus surface protein involved in biofilm formation. J. Bacteriol., 183(9): 2888-2896.

9. Azara, E., Longheu, C., Sanna, G. and Tola, S. (2017) Biofilm formation and virulence factor analysis of Staphylococcus aureus isolates collected from ovine mastitis. J. Appl. Microbiol., 123(2): 372-379.

10. Aslantaş, Ö. and Demir, C. (2016) Investigation of the antibiotic resistance and biofilm-forming ability of Staphylococcus aureus from subclinical bovine mastitis cases. J. Dairy Sci., 99(11): 8607-8613.

11. Thompson, A. and Brown, P.D. (2017) Association between the AGR locus and the presence of virulence genes and pathogenesis in Staphylococcus aureus using a Caenorhabditis elegans model Terissa. Int. J. Inf. Dis., 54: $72-76$

12. Bibalan, M., Shakeri, F., Javid, N., Ghaemi, A. and Ghaemi, E. (2014) Accessory gene regulator types of Staphylococcus aureus isolated in Gorgan, North of Iran. J. Clin. Diagn. Res., 8(4): DC07-DC09.

13. Oliver, S.P., Gonzalez, R.N., Hogan, J.S., Jayarao, B.M. and Owens, W.E. (2004) Microbiological Procedures for the Diagnosis of Bovine Udder Infection and Determination of Milk Quality. $4^{\text {th }}$ ed. National Mastitis Council, Madison.

14. Quinn, P.J., Market, B.K., Leonard, F.C., Patrick, E.S.F., Fanning, S. and Hartigan, P.J. (2011) Veterinary Microbiology and Microbial Disease. $2^{\text {nd }}$ ed. WileyBlackwell, Chichester

15. Mason, W.J., Blevins, J.S., Beenken, K., Wibowo, N., Ojha, N. and Smeltzer, M.S. (2001) Multiplex PCR protocol for the diagnosis of staphylococcal infection. J. Clin. Microbiol., 39(9): 3332-3338.

16. Ciftci, A., Findik, A., Onuk, A. and Savasan, S. (2009) Detection of methicillin resistance and slime factor production Staphylococcus aureus in bovine mastitis. Braz. J. Microbiol., 40(2): 254-261.

17. Vancraeynest, D., Hermans, K. and Haesebrouck, F. (2004) Genotypic and phenotypic screening of high and low virulence Staphylococcus aureus isolates from rabbits for biofilm formation and MSCRAMMs. Vet. Microbiol., 103(34): $241-247$

18. Abd El-Hamid, M.I. and Bendary, M.M. (2013) Association between AGR alleles and toxin gene profiles of $S$. aureus isolates from human and animal sources in Egypt. Int. $J$. Adv. Res., 1(8): 33-144.

19. Tristan, A., Ying, L., Bes, M., Etienne, J., Vandenesch, F. and Lina, G. (2003) Use of multiplex PCR to identify Staphylococcus aureus adhesins involved in human hematogenous infections. J. Clin. Microbiol., 41(9): 4465-4467.

20. Ruegg, P.L. (2017) A 100-year review: Mastitis detection, management, and prevention. J. Dairy Sci., 100(12): 10381-10397.

21. Monistero, V., Graber, H., Pollera, C., Cremonesi, P., Castiglioni, B., Bottini, E., Marquez, A.C., Rojas, L.L., 
Kroemker, V., Wente, N., Petzer, I., Santisteban, C., Runyan, J., Santos, M., Alves, B., Piccinini, R., Bronzo, V., Abbassi, M.S., Said, M. and Moroni, P. (2018) Staphylococcus aureus isolates from bovine mastitis in eight countries: Genotypes, detection of genes encoding different toxins and other virulence genes. Toxins, 10(6): 247.

22. Abdelazeem, M.A., Enany, M.E., El-Tarabili, R.M., Ghobashy, M.O.I. and Helmy, Y.A. (2020) Prevalence, antimicrobial resistance profiles, virulence and enterotoxins-determinant genes of MRSA isolated from subclinical bovine mastitis in Egypt. Pathogen, 9(5): 362.

23. Haltia, L., Honkanen-Buzalski, T., Spiridonova, I., Olkkonen, A. and Myllys, V. (2006) A study of bovine mastitis, milking procedures and management practices on 25 Estonian dairy herds. Acta Vet. Scandal., 48(1): 22.

24. Cosgrove, S.E. (2006) The relationship between antimicrobial resistance and patient outcomes: Mortality, length of hospital stay, and health care costs. Clin. Infect. Dis., 42(Suppl 2): S82-S89.

25. Neopane, P., Nepal, H.P., Hrestha, R., Uehara, O. and Abiko, Y. (2018) In vitro biofilm formation by Staphylococcus aureus isolated from wounds of hospital-admitted patients and their association with antimicrobial resistance. Int. J. Gen. Med., 11: 25-32.

26. Namvar, A.E., Asghari, B., Ezzatifar, F., Azizi, G. and Lari, A.R. (2013) Detection of the intercellular adhesion gene cluster (Ica) in clinical Staphylococcus aureus isolates. GMS Hyg. Infect. Control, 8(1): Doc03.

27. Atshan, S.S., Shamsudin, M.N., Sekawi, Z., Lung, L., Hamat, R.A., Karunanidhi, A., Ali, A.M., Ghaznavi-Rad, E., Moghaddam, H.G., Seng, J.S.C., Nathan, J.J. and Pei, C.P. (2012) Prevalence of adhesion and regulation of biofilm-related genes in different clones of Staphylococcus aureus. J. Biomed. Biotechnol., 2012: 976972.

28. Gowrishankar, S., Kamaladevi, A., Balamurugan, K. and Pandian, S.K. (2016) In vitro and in vivo biofilm characterization of methicillin-resistant Staphylococcus aureus from patients associated with pharyngitis infection. Biomed Res. Int., 2016: 1289157.

29. Avila-Novoa, M., Iñiguez-Moreno, M., Solís-Velázquez, O. and González-Gómez, J.P. (2018) Biofilm formation by Staphylococcus aureus isolate from food contact surfaces in the dairy industry of Jalisco, Mexico. J. Food Qual., 2018: 1746139.

30. Cucarella, C., Tormo, M.A., Ubeda, C., Pilar-Trotonda, M., Monzon, M., Peris, C., Amorena, B., Lasa, I. and Penades, J.S. (2004) Role of biofilm associated protein Bap in the pathogenesis of bovine Staphylococcus aureus. Infect. Immun., 72(4): 2177-2185.

31. Vautor, E., Magnone, V., Rios, G., Le Brigand, K., Bergonier, D., Lina, G., Meugnier, H., Barbry, P., Thiéry, R. and Pépin, M. (2009) Genetic differences among Staphylococcus aureus isolates from dairy ruminant species:
A single-dye DNA microarray approach. Vet. Microbiol., 133(1-2): 105-14.

32. Bissong, M.E.A. and Ateba, C.N. (2020) Genotypic and phenotypic evaluation of biofilm production and antimicrobial resistance in Staphylococcus aureus isolated from Milk, North West Province, South Africa. Antibiotics, 9(4): 156.

33. Li, L., Yang, H.J., Liu, D.C., He, H.B., Wang, C.F., Zhang, J.F., Gao, Y.D. and Yangjun, Z. (2012) Analysis of biofilm formation and associated genes detected in Staphylococcus isolates from bovine mastitis. Intern. J. Appl. Res. Vet. Med., 10(1): 62-68.

34. Xu, J., Tan, X., Zhang, X., Xia, X. and Sun, H. (2015) The diversities of staphylococcal species, virulence and antibiotic resistance genes in subclinical mastitis milk from a single Chinese cow herd. Microb. Pathog., 88: 29-38.

35. Khoramrooz, S.S., Mansouri, F., Marashifard, M., Hosseini, S.A.M., Chenarestane-Olia, F.A., Ganavehei, B., Gharibpour, F., Shahbazi, A., Mirzaii, M. and Khalil, D.D.S. (2016) Detection of biofilm related genes, classical enterotoxin genes and AGR typing among Staphylococcus aureus isolated from bovine with subclinical mastitis in Southwest of Iran. Microb. Pathog., 97: 45-51.

36. Darwish, S.F. and Asfour, H.A. (2013) Investigation of biofilm forming ability in staphylococci causing bovine mastitis using phenotypic and genotypic assays. Sci. World J., 2013: 378492.

37. Peerayeh, S.N., Azimian, A., Nejad, Q.B. and Kashi, M. (2009) Prevalence of agr specificity groups among Staphylococcus aureus isolates from university hospitals in Tehran. Lab. Med., 40(1): 27-29.

38. Ote, I., Taminiau, B., Duprez, J.N., Dizier, I. and Mainil, J.G. (2011) Genotypic characterization by polymerase chain reaction of Staphylococcus aureus isolates associated with bovine mastitis. Vet. Microbiol., 153(3-4): 285-292.

39. Ikawaty, R., Brouwer, E.C., Van Duijkeren, E., Mevius, D., Verhoef, J. and Fluit, A.C. (2010) Virulence factors of genotyped bovine mastitis Staphylococcus aureus isolates in the Netherlands. Int. J. Dairy Sci., 5(2): 60-70.

40. Javdan, S., Narimani, T., Abadi, M. and Gholipour, A. (2019) Agr typing of Staphylococcus aureus species isolated from clinical samples in training hospitals of Isfahan and Shahrekord. BMC Res. Notes, 12(1): 363.

41. Cheraghi, S., Pourgholi, L., Shafaati, M., Fesharaki, S.H., Jalali, A., Nosrati, R. and Boroumand, M.A. (2017) Analysis of virulence genes and accessory gene regulator (agr) types among methicillin-resistant Staphylococcus aureus strains in Iran. J. Glob. Antimicrob. Resist., 10: 315-320.

42. Pereyraa, E.A.L., Picech, F., Rennaa, M.S., Baravalle, C., Andreottia, C.S., Russic, R., Calvinhod, L.F., Diez, C.N. and Dallarda, B. (2015) Detection of Staphylococcus aureus adhesion and biofilm-producing genes and their expression during internalization in bovine mammary epithelial cells. Vet. Microbiol., 183: 69-77. 